\title{
Investigation of LFA-1 rs2230433 Variation in Renal Cell Carcinoma Tissues
}

\section{Halime Hanım Pençe1, (1) Hani Alsaadoni2, (1) Burcu Çaykara², (1) Alper Ötünçtemur ${ }^{3}$, Sibel Kuraş ${ }^{1}$, (D) Bengü Tokat ${ }^{2}$}

${ }^{1}$ Department of Medical Biochemistry, University of Health Sciences, Faculty of Medicine, Istanbul, Turkey ${ }^{2}$ Department of Molecular Medicine, Istanbul University, Aziz Sancar Institute of Experimental Medicine (ASDETAE), Istanbul, Turkey

${ }^{3}$ Department of Urology, University of Health Sciences, Faculty of Medicine, Istanbul, Turkey

\begin{abstract}
Introduction: Leukocyte function-related antigen-1 (LFA-1) is a 3 heterodimeric transmembrane glycoprotein and expressed on the surface of leukocytes. LFA-1 also interacts with intercellular adhesion molecules 1 (ICAM-1) which is related to cancer. Variation in LFA-1 can affect the carcinogenesis; thus, we aimed to investigate rs2230433 variation in renal cell carcinoma.

Methods: One hundred renal cell carcinoma tissues and healthy surrounding tissue of the same kidney formed the tumor and control groups, respectively. DNA isolated from the tissues and polymerase chain reaction (PCR)-restriction fragment length polymorphism (RFLP) methods were employed. Statistical analysis was performed with SPSS 22.0, and $p<0.05$ was considered as statistically significant.

Results: LFA-1 rs2230433 GC and CC genotypes were found similar between tumor and control groups ( $p>0.05)$. However, GG genotype was higher in tumors (8\%) than controls (2\%).

Discussion and Conclusion: Our results showed that normal GG genotype is higher in tumors. Thus, GG genotype can be related to tumorigenic features.

Keywords: Renal cell carcinoma; LFA-1; rs2230433.
\end{abstract}

$\mathrm{R}^{-1}$ enal cell carcinoma (RCC), which constitutes 2-3\% of adult cancers, ranks seventh in men and ninth in women ${ }^{[1]}$. Leukocyte function-related antigen-1 (LFA-1), aL $\beta 2$ integrin, is also called CD11a/CD18 or ITGAL. LFA-1 is $a \beta$ heterodimeric transmembrane glycoprotein containing I-domain and expressed on the surface of leukocytes [2]. The LFA-1 gene is localized on chromosome $16 \mathrm{p} 11.2$ ${ }^{[3]}$. Fu et al. ${ }^{[4]}$ suggested that the variation of rs2230433 in the LFA-1 gene may affect the function and expression of LFA-1 in the development of sporadic infiltrative breast cancer. Tokat et al. ${ }^{[5]}$ found that rs 2230433 was associated with Turkish breast cancer patients. Thus, we aimed to investigate rs 2230433 variation in renal cell carcinoma to contribute to the literature. To our knowledge, the present study is the first research into rs2230433 variation in renal cell carcinoma. 


\section{Materials and Methods}

One hundred renal cell carcinoma tissues and healthy surrounding tissue of the same kidney formed the tumor and control groups, respectively. DNA was extracted with QIAzol Lysis Reagent (QIAGEN) from tissue samples. The study protocol was approved by the Ethical Committee of Okmeydanı Educational and Research Hospital (No: 1341, 2019). Detecting of rs 2230433 (in exon 21) was performed with polymerase chain reaction and restriction fragment length polymorphism (PCR-RFLP) methods. Primer sequences were forward 5'-GATATTCCCCACCCTGATCC-3' and reverse 5'-CACCTTCAGCATCTCCACCT-3'. PCR amplification contents and conditions in a thermal cycler ( $\left(\mathrm{T} 100^{\mathrm{TM}}{ }^{\mathrm{N}}, \mathrm{BioRad}\right)$ were given in Table 1 and 2, and 200 bp PCR product were controlled with agarose gel electrophoresis and UV light. $10.25 \mu \mathrm{l}$ reaction mixture with Banll restriction enzyme (0.25 $\mu$ l Banll enzyme (10 u/ $\mu \mathrm{l}), 0.5 \mu \mathrm{l}$ 10X Tango buffer, 4.5 $\mu \mathrm{l}$ distilled water and $5 \mu \mathrm{l}$ PCR product) were incubated at $37^{\circ} \mathrm{C}$ for 16 hours. RFLP products were visualized under UV light after agarose gel electrophoresis containing ethidium bromide. 135 and 65bp with normal G allele (Arg707) and 200bp with mutant $C$ allele (Thr707) were observed.

\section{Statistical Analysis}

Statistical analysis was performed using SPSS software for Windows, version 22.0 (IBM Corp., Armonk, NY, USA). The rs2230433 variation genotypes and alleles in tumor and control groups were evaluated with the chi-square test. P-value less than 0.05 was considered as statistically significant.

Table 1. PCR contents for $r s 2230433$

\begin{tabular}{lc}
\hline PCR contents & Amount \\
\hline DNA (100ng) & $1 \mu \mathrm{l}$ \\
10XTaq buffer (Fermentas) & $1.5 \mu \mathrm{l}$ \\
$25 \mathrm{mM} \mathrm{MgCl}$ (Fermentas) & $1.5 \mu \mathrm{l}$ \\
$50 \mathrm{pmol} / \mu \mathrm{l}$ primers & 2 \\
$5 \mathrm{U}$ Taq DNA polymerase (Fermentas) & $0.3 \mu \mathrm{l}$ \\
Distilled water & $18.7 \mu \mathrm{l}$ \\
Total & $25 \mu \mathrm{l}$ \\
\hline
\end{tabular}

Table 2. PCR conditions for $r s 2230433$

\begin{tabular}{lcc}
\hline Temperature & \multicolumn{2}{c}{ Time and Cycle } \\
\hline $94{ }^{\circ} \mathrm{C}$ & \multicolumn{2}{c}{$5 \mathrm{~min}$} \\
$94^{\circ} \mathrm{C}$ & $45 \mathrm{~s}$ & \\
$59^{\circ} \mathrm{C}$ & $45 \mathrm{~s}$ & 30 Cycles \\
$72^{\circ} \mathrm{C}$ & $45 \mathrm{~s}$ & \\
$72{ }^{\circ} \mathrm{C}$ & \multicolumn{2}{c}{$5 \mathrm{~min}$} \\
\hline
\end{tabular}

\section{Results}

The mean age of the patients with renal cell carcinoma was $59.78 \pm 11.14$. LFA-1 rs2230433 variation was found in Hardy-Weinberg equilibrium ( $p>0.05$ ) (Table 3). LFA-1 rs2230433 GC and CC genotypes were found similar between tumor and control groups ( $p>0.05)$. However, GG genotype was higher in tumors (8\%) than controls (2\%). No significant difference was observed between genotype and allele comparisons ( $p>0.05$ ) (Table 3). On the other hand, $\mathrm{GC}+\mathrm{CC}$ genotype was found slightly significant to the GG genotype $(p=0.052)$. Since the genotype comparison of the tissues of the same person was performed in our study, this may mean that there was a mutation in the direction of GG genotype in tumor formation.

\section{Discussion}

LFA-1 rs2230433 GG genotype was found 8\% in the tumor group, while $\% 2$ in the control group. The ratio of mutant CC and heterozygote GC genotypes were similar in the groups. No significant difference was observed between genotypes and alleles ( $p>0.05$ ).

LFA-1 is expressed on leukocytes and not only functions as adhesion molecule but also mediates the signals of growth, differentiation and survival. LFA-1 also interacts with intercellular adhesion molecules 1 (ICAM-1), which is related to cancer ${ }^{[6]}$. It was shown that disrupted LFA1-ICAM-1 interaction in cancer models increases the presence of activated CD8+ T cells he incidence of tumor-

Table 3. Hardy-Weinberg equilibrium for LFA-1 rs2230433 variation

\begin{tabular}{lcccc}
\hline Groups & $\begin{array}{c}\text { Genotypes } \\
\mathbf{n}\end{array}$ & $\begin{array}{c}\text { Observed } \\
\mathbf{n}\end{array}$ & Expected & $\mathbf{p}$ \\
\hline Tumor & GG & 8 & 5 & 0.052 \\
& GC + CC & 92 & 95 & \\
Control & GG & 2 & 5 & \\
& GC + CC & 98 & 95 & \\
& & &
\end{tabular}

Table 4. Genotypes and alleles distributions in tumor and control groups for LFA-1 rs2230433 variation

\begin{tabular}{lcccc}
\hline LFA-1 rs2230433 & $\begin{array}{c}\text { Tumor } \\
\mathbf{n}(\%)\end{array}$ & $\begin{array}{c}\text { Control } \\
\mathbf{n}(\%)\end{array}$ & OR (\%95CI) & p \\
\hline G & $88(44)$ & $81(40.5)$ & reference & \\
C & $112(56)$ & $119(59.5)$ & $1.15(0.78-1.72)$ & 0.48 \\
GG & $8(8)$ & $2(2)$ & reference & \\
GC & $72(72)$ & $77(77)$ & $4.28(0.879-20.82)$ & 0.052 \\
CC & $20(20)$ & $21(21)$ & $4.2(0.794-22.22)$ & 0.075 \\
GC + CC & $92(92)$ & $98(98)$ & $4.26(0.882-20.59)$ & 0.052 \\
\hline
\end{tabular}


draining lymph nodes [7]. Thus, LFA-1/ICAM-1 pathway plays an important role in in the protection from infections and cancer via activation and function of $\mathrm{T}$ cell trafficking ${ }^{[8]}$.

The $\mathrm{G}>\mathrm{C}$ change in exon 21 of the ITGAL gene encoding LFA-1 leads to the threonine amino acid coding (Arg707Thr) instead of the arginine amino acid [9, 10]. LFA-1 rs2230433 variation was found associated with hepatitis B, allergic disease and Graves' disease [11-13]. However, rs2230433 was not found associated with Behçet's disease and hepatitis B virus-related hepatocellular carcinoma $[9,14]$. Furthermore, rs2230433 genotypes were not also found statistically significant among German malignant melanoma patients $(p>0.05)^{[15]}$. On the other hand, Fu et al. ${ }^{[4]}$ reported that GG genotype and $G$ allele of rs2230433 were lower in sporadic infiltrative duct breast carcinoma (SIDBC) $(p<0.05)$. Heterozygote GC genotype was found higher in the same study. Another study found that the frequency of the LFA-1 rs2230433 $\mathrm{G}$ allele was $43.52 \%$ in breast cancer patients and $37.3 \%$ in controls ${ }^{[5]}$. In our study, we found $\mathrm{G}$ allele was $44 \%$ in renal cell carcinoma, while $40.5 \%$ in the control group. Mutant C allele was $56 \%$ and $59.5 \%$ in tumor and control groups, respectively ( $p>0.05)$. GG genotype was higher in renal cell carcinoma tissues than surrounding healthy renal tissues ( $8 \%$ vs $2 \%$ ), while mutant CC genotype was similar in the tissues ( $20 \%$ vs $21 \%$, respectively). Because the tumor and healthy tissues belong to the same person, we can suggest that there was a mutation $C$ to $G$ in tumor although normal genotype is GG, patients had especially heterozygote GC genotype. Based on this result with the available limited data, the findings suggest that GG genotype in the presence of tumor may positively affect tumor development. We completed our study with 100 tumors and 100 healthy renal tissues, but the number of samples should be increased for the interpretation to be healthier. If the GG genotype is found more in tumor tissues when the results are repeated, it would be valuable to evaluate the potential effects of Arg707Thr change on the function of LFA-1. However, this study should include sequencing of the LFA-1 gene as well as gene expression. In this case, it will be possible to reveal other variations that may affect the function of LFA-1. As a result, we did not find statistically significant LFA-1 rs2230433 in renal cell carcinoma. However, higher GG genotype in tumor tissues can be valuable to evaluate this variation with higher sample groups and GG genotype can be related to the tumorigenic profile.
Ethics Committee Approval: The study protocol was approved by the Ethical Committee of Okmeydanı Educational and Research Hospital (No: 1341, 2019).

Peer-review: Externally peer-reviewed.

Conflict of Interest: None declared.

Financial Disclosure: The authors declared that this study received no financial support.

\section{References}

1. Girgin R, Akduman B. Berrak Hücreli Renal Kanserde Prognostik Biyobelirteçler. Böbrek Kanseri 2017;1:133-137.

2. Hynes RO. Integrins: versatility, modulation, and signaling in cell adhesion. Cell 1992;69:11-25.

3. Callen DF, Chen LZ, Nancarrow J, Whitmore SA, Apostolou S, Thompson AD, Lane SA, Stallings RL, Hildebrand CE, Harris PG, Sutherland GR. Current state of the physical map of human chromosome 16. Cytogenet. Cell Genet 1991; 58.

4. Fu Z, Jiao M, Zhang M, Xu F, Yuan W, Pang D, et al. LFA-1 gene polymorphisms are associated with the sporadic infiltrative duct breast carcinoma in Chinese Han women of Heilongjiang Province. Breast Cancer Res Treat 2011;127:265-71.

5. Tokat B, Ozturk T, Seyhan MF, Calay Z, Ilvan S, Tuzuner MB, et al. Interactive Effects of Common Haplotypes of Two Leukocyte Diapedesis-Related Genes, LFA- 1 and JAM-A on Breast Cancer Risk. International Journal of Hematology and Oncology 2018;1:45-52.

6. Reina M, Espel E. Role of LFA-1 and ICAM-1 in Cancer. Cancers (Basel) 2017;9:pii:E153.

7. Yanguas A, Garasa S, Teijeira Á, Aubá C, Melero I, Rouzaut A. ICAM-1-LFA-1 Dependent CD8+ T-Lymphocyte Aggregation in Tumor Tissue Prevents Recirculation to Draining Lymph Nodes. Front Immunol 2018;9:2084.

8. Harjunpää H, Llort Asens M, Guenther C, Fagerholm SC. Cell Adhesion Molecules and Their Roles and Regulation in the Immune and Tumor Microenvironment. Front Immunol 2019;10:1078.

9. Park SR, Park KS, Park YJ, Bang D, Lee ES. CD11a, CD11c, and CD18 gene polymorphisms and susceptibility to Behçet's disease in Koreans. Tissue Antigens 2014;84:398-404.

10. Nielsen KR, Koelbaek MD, Varming K, Baech J, Steffensen R. Frequencies of HNA-1, HNA-3, HNA-4, and HNA-5 in the Danish and Zambian populations determined using a novel TaqMan real time polymerase chain reaction method. Tissue Antigens 2012;80:249-53.

11. Posteraro B, Pastorino R, Di Giannantonio P, lanuale C, Amore $R$, Ricciardi $W$, et al. The link between genetic variation and variability in vaccine responses: systematic review and metaanalyses. Vaccine 2014;32:1661-9.

12. Knight JM, Lee SH, Roberts L, Smith CW, Weiss ST, Kheradmand $F$, et al. CD11a polymorphisms regulate $\mathrm{TH} 2$ cell 
homing and TH2-related disease. J Allergy Clin Immunol 2014;133:189-97.e1-8.

13. Yang G, Fu Y, Lu X, Wang M, Dong H, Li Q. The interactive effects of genetic polymorphisms within LFA-1/ICAM-1/GSK-3 $\beta$ pathway and environmental hazards on the development of Graves' opthalmopathy. Exp Eye Res 2018;174:161-172.

14. Shang L, Ye X, Zhu G, Su H, Su Z, Chen B, et al. Prognostic value of integrin variants and expression in post-operative patients with HBV-related hepatocellular carcinoma. Oncotarget 2017;8:76816-76831.

15. Lenci RE, Rachakonda PS, Kubarenko AV, Weber AN, Brandt A, Gast $A$, et al. Integrin genes and susceptibility to human melanoma. Mutagenesis 2012;27:367-73. 